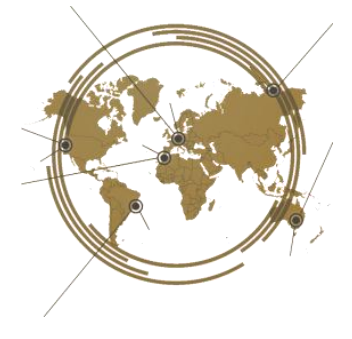

\title{
Dysfunctional American dream reflected in Arthur Miller's death of a salesman
}

\author{
Ivana Nabilah Qoriroh Mujahidah*, Agista Nidya Wardani \\ English Language Education Department, Universitas Muhammadiyah Malang, Indonesia
}

The research aims to find the dysfunctional American Dreams; the causes of dysfunctional American Dreams and the effects of dysfunctional American Dreams experienced by the main character, Willy Lowman, as a representation of American society. This paper conducted by applying descriptive qualitative research which is naturally interpretative. Thus, the key instrument is the researcher herself who has the authority in managing and analyzing the data, and certainly producing meaning in the process of discussion and interpretations. This study, theoretically, applied the mimetic theory as the research approach. The researcher found that Miller uses the character of Willy Lowman to represent the failure of the American Dream. Willy's quest for the American Dream leads to his failure because throughout his life he pursues the illusion of the American Dream. Tragically, the effect of his failure was committing a suicide, where to himself it was not a failure but a success, since there will be many people come to his funeral as a symbol of fame and he will inherit a lot of insurance money for his family. A theoretical analysis through this study represented that not all Americans or immigrants have the same perception of the American Dreams and not all of them can reach the dreams.

Keywords: Dysfunctional, American Dream, Capitalism

OPEN ACCESS

ISSN 25033492 (online)

${ }^{*}$ Correspondence: Ivana Nabilah Qoriroh Mujahidah ivanamimanarulislam2017@gmail.com

Received: 30th November 2020 Accepted: 2nd November 2021

Published: 5th November 2021

Citation:

Mujahidah, I. N. Q. and Wardani, A. N. (2021). Dysfunctional American dream reflected in Arthur Miller's death of salesman.

J. Eng. Educ. Society. 6:2. doi:10.21070/jees.v6i2.1077

\section{INTRODUCTION}

The American identity, unlike other national identities that are rooted in a shared history, religion or race, is primarily rooted in an American Dream. The American national identity is about the collective values of equal opportunity and the pursuit of happiness as stated in American Declaration of Independence primary written by Jefferson (1776):

We hold these truths to be self-evident, that all men are created equal, that they are endowed by their Creator with certain unalienable right, that among there are Life, Liberty and the pursuit of Happiness (Congress Document, July 4th, 1776).

American success is meant to be equally accepted by everybody, and attainable through work hard and perseverance. However, not all people could successfully reach the dream for some reasons. This condition is illustrated in a play Death of a Salesman by Arthur Miller exposing the dysfunction of the American Dream. It addresses loss of identity and a man's inability to accept change within themselves and society. The play constitutes a montage of memories, dreams, confrontations, and arguments, all of which make up the last twenty-four hours of Willy Lowman's life as the main character.

Moreover, instead of American Dream, there is also an effect of capitalism that portrayed in Arthur Miller's Death of a Salesman. According to Gailan (2016), Marx believed that society is divided into two groups, the bourgeoisie and the proletarians. 
Willy Lowman is a salesman who has big expectations of his life without considering a situation that he has. In brief, Willy Lowman belongs to proletarians and he obliquely has been discriminated by the system of capitalism in which American Dream is the ideology of capitalism itself.

According to Can (2019) Death of a Salesman is the play depicts a period in which the negative effects of the Great Depression in twentieth century tragedy with a tragic-I hero. Several studies about the American Dream reflected in Arthur Miller's Death of a Salesman have been conducted by some former researchers. First, Nzisi (2017) examined Lowman's American Dream's perception to prove whether he achieves it or not. He found that the perception of Willy Lowman about being well-liked would help him achieve his American Dream, and Willy Lowman took his life to show disillusionment. The failure to achieve the American Dream caused the family to collapse, and Willy got the point where life was meaningless, so he was better off the dead.

Furthermore, Mgamis (2017) examined about the excessive inclination towards individualism and greed as represented in the major character in the play, Willy Lowman, as the idealistic version of the dream or fantasy and blind. The result of the study was that Willy's greedy version of American Dream made him collapse and the problem was not in the American Dream but in his version how to apply it. Meanwhile, Elhawa (2018) talked about the concept of American Dream based on Lacanian perspective. He does not only focus on the main character but also to the other characters by comparing the way they pursuit their dream. He found that after his pursuit of the dream, Willy finally decided to die, led him to total failure. His tragic failure could be attributed to his blurred vision of reality brought about by his drive to fulfill his desires, and the exact destination of ecstasy was empty from the Lacanian perspective.

It is clear that the concept of American Dream has been researched widely. In the studies mentioned earlier, scholars have looked at the American Dream concept in both the contemporary and literary aspects. However, by reviewing the previous research, the researcher underlines that none of the previous studies discussed dysfunction of American Dream in Arthur Miller's Death of a Salesman. The researcher would like to display dysfunctional of American Dream as the weakness of American Dream and how capitalism influenced people who is living with American Dream.

Therefore, this study intends to investigate the dysfunctional American Dream faced by Willy Lowman, the causes of failure in achieving American Dream, and the effect of Willy Lowman's failure on achieving his dream based on the theory of American Dream and Capitalism theoretical perspective.

\section{METHODS}

The researcher described the phenomena in the play in order to dig up detailed information about dysfunctional American Dream in Arthur Miller's Death of a Salesman, especially on the main character, Willy Lowman. The data of this study were taken from the Arthur Miller's Death of a Salesman published by Penguin Books, New York, USA, in 1998.

This study applied the mimetic theory (Abrams, 1971) as the research approach. The mimetic theory assists the researcher to relate the play and universe. The term universe refers to all of things of the world apart from audience, text, and author. The researcher started to use mimetic approach by understanding the value that inherent in Death of a Salesman and observing the history of American Dreams, Capitalism, also global issues in America. According to Miller (2015) this drama has been written as a critical literary work towards American Dreams and Capitalism based on The Great Depression phenomena. This mimetic approach emphasizes how to relate a literary works into universal truths.

Meanwhile, the researcher also used two supporting theories, the concept of American Dream (Castle, 2018) and Capitalism theoretical perspective (Gailan, 2016; Hodgson, 2015) to strengthen the analysis of this thesis. The concept of American Dream enables the researcher to identify the American values or ideals in the story where the ideals as the very fundamental values are almost embedded in the mind of all Americans. Of course, to know the dysfunctions of the ideals are unavoidably important. In the meantime, Capitalism theoretical perspective (Gailan, 2016; Hodgson, 2015) used to analyze the social structures that exist in a capitalist society where the ideology of capitalism leads to fragmentation and alienation of individuals, particularly those of the proletariat.

However, in order to make the analysis is not subjective, the researcher used triangulation theory of the relationship of the economy, politics, and society in the absence of grand theory or universal law of social development such as Marxism, on the other hand, Modernization theory (Girling, 2002). This theory used comparatives perspective of Webern ideal-type models to provide the organizing principle. In this sense, historical investigation over a sufficiently lengthy period of time-from decades or more-reveals. This theory took place in analyzing the problem of capitalism in Arthur Miller's Death of a Salesman and the researcher used Willy Lowman as the representative.

In collecting the data, the researcher did three stages of the reading processes by applying Riffaterre's reading strategies from heuristic reading to retroactive reading (Nurgiyantoro, 2005). The details of the reading processes are reading the whole text to get a general understanding, rereading the script to get a comprehensive understanding, rereading the script and coding the data needed in accordance with the research questions. In coding the data, the researcher coded the data manually and analyzed. 


\section{RESULTS AND DISCUSSION}

After comprehending some related theories and conducting thorough reading processes, the researcher found some recitations in the dialogues that meet the qualification of being data, since they are closely related with the research problems.

\section{The Dysfunctional American Dreams Faced by Willy Lowman}

\section{Willy Lowman's Utopia}

Willy Lowman is a travelling salesman who still adheres to the traditional model of frontier salesman. He believes that the idea of success relied on leaving the house for a long time and coming back with a large amount of money. Willy Lowman is an idealistic individual who has a lot of big dreams that actually based on fantasy. Throughout his life, he has created elaborate narratives that refute the increasing proof of his inability to satisfy his desires and expectations. $\mathrm{He}$ is always daydreaming in his reality of life. At the time the play ends, Willy suffers from debilitating self-delusion. His mind is so fragmented that he cannot even sustain a coherent image. Miller, in the play, wrote the speech of Charley, Willy's friend; "He's a man way out there in the blue, riding on a smile and a shoeshine.”(Req., p. 111)

Charley's talk in a requiem about the essence of the salesman's dreams praises Willy as a victim of his demanding career. His poetic sales appraisal defends Willy's death, attributing to Willy's work the kind of magical quality that Willy himself has always dreamed. Charley compares the salesman to a courageous, brave sailor, "out there in the sea," (Req., p. 111) with little to guide him and persuasive powers to deal with. Charley also points out that there is a significant difference between the enormousness of the salesman's job and the piddling devices for which he is equipped: Willy had only an insubstantial grin on his face and the shine of his shoe with which to sell himself. Failure ruined Willy's smile and smudged his shoe, making it much harder to sell. Besides, he always convinces other people with his past success and prides himself that he is a very well-known and liked person.

Willy [banging his hand on the desk]: I averaged a hundred and seventy dollars a week in the year of 1928 !

And your father came to me-or rather, I was in the office here - it was right over this desk - and he put his hand on my shoulder-(Act. 2, p. 62).

This dialogue happened in the scene when Willy is talking to Howard, his boss. Willy is trying to get a full-pay job in New York and he does not have to be a travelling salesman anymore. Some dialogues below also demonstrate that Willy's mind is money oriented, as if he cannot life without money and his social status depends on the money he has. According to Datesman, Crandal, and Kearny (2014) one of the American values is material wealth where America seemed to be a land of abundance and million people might come to seek their fortune. Almost all workers work to pursue happiness by earning much money. In line with that notion, Perry (2000) obviously states that American prosperity can be measured by the number of things they bought and owned. Thus, it makes American become more materialistic. Willy, now, is in his sixty-threeyear-old and he loses his sense of direction easily. He is also tired.

However, Willy really needs money to survive, "But I gotta earn money, Howard. I'm in no position to $\neg \neg-$ " (Willy, Act. 2, p. 63) and has never had a job in the company where he has made an actual, steady paycheck because he only works on commissions, "He's off salary. My God, working on commission!" (Biff, Act. 1, p. 40). This phenomenon shows that Willy does not ready to face his real life in the present. He lives in a fantasy that makes him get a mental illness. Willy's dream is closely related with an American ethos with hope, prosperity, and success within freedom. As insisted by Fiedler (2000) that American dream is the dream which life should be better, richer, and fuller for each man with opportunities for each according to his ability and achievement. However, Willy may have an opportunity to be successful but he does not realize his age that sometimes makes him lost his sense of direction easily.

On the other hand, Willy's life is full of daydreaming and he does not realize that he never tell the truth and see the reality. Biff, ironically, is realizing the failure of his father, he considers that all Willy's teaching as lies. He said, "we never told the truth for ten minutes in this house" (Biff, Act. 2). It seems like Willy was, by all accounts, a miserable man. Simply, when Willy sees a little chance to change his life, he directly thinks about a big deal that can happen in the future with his million dollars ideas by ignoring his abilities and opportunities he has. For example, when Biff has a plan to meet Bill Oliver to go into his business, Willy seems so relieved and enthusiastically speaking about the future. He says to Biff to start it bravely, "But remember, start big and you'll end big. Ask for fifteen. How much you going to ask for?"(Act. 1, p. 47) and it is continued in the next dialogue when Willy starts offering some unhelpful advices for Biff's loan interview.

"Don't be so modest. You always started too low. Walk in with a big laugh. Don't look worried. Start off with couple of your good stories to lighten things up, It's not what you say, it's how you say it- because personality always wins the day"(Act. 1, p. 48)

One reason Willy's reluctance to criticize Biff for his youthful robberies and his reckless attitude toward his classes seems to be that he fears Biff's ego could be damaged. He, therefore, gave endless praise, hoping that in 
his adulthood Biff would fulfill the promise of that praise. It is also possible that Willy fails to criticize the young Biff, as he believes that, if he does, Biff will not accept him. This rejection is the greatest personal and professional provocation and failure (the two worlds are conflated in Willy's mind). Because the consciousness of Willy is divided between despair and hope, both considerations are likely to be behind the decision of Willy not to criticize the youthful indiscretions of Biff. In any event, his relationship with Biff is rife with the side of Willy's childhood emotional rejection trauma, and the conflict between Biff's side meeting social expectations and personal expectations.

Theoretically, speaking, the idea of the American Dream has the most significant influence on those who do not enjoy the prosperity and happiness that it promises. According to Adams (1931), the first historian who first coined the term American dream, American dream is the pursuit of a better, richer and happier life for all American of all ranks as the greatest contribution we have made to the world's thought and welfare. This vision is actually emerged from the values shown in Jefferson (1776) America Declaration of Independence which highlighted the right people to "life, liberty, and the pursuit of happiness" (Fiedler, Jansen, Norman-Rich, 2000). Willy pursues the fruits of that vision as a panacea to the deceptions and hurts of his childhood.

\section{Willy Lowman's Perception of American Dream}

Willy Lowman is a salesman who has sold merchandise for a company for 36 years. He believes that one can be prosperous if they are known and are 'well-liked.' In his past fifteen years, he is liked by all the people he sells items to across the country but as he grows older, most people forget him. This makes Willy looks so miserable and he is very desperate. He expresses in some of his dialogues:

"I'm very well liked in Hartford. You know, the trouble is, Linda, people don't seem to take me...I know it when I walk in. They seem to laugh at me...but they just pass me by, I'm not noticed" (Act. 1. P. 23)

Fortunately, he has a wife who loves him and always supports him. However, he also has two sons, Biff and Happy, who are not set up in life. As we know, the Lowman's family is a middle class family and they really want to be successful in life. From Willy's expressions about not being 'well-liked' anymore, he dreams of being prosperous. He is a salesman who gets a chance to interact with a lot of people and he assumes that everyone knows and likes him. He strongly believes that those are the keys of success.

Willy: You and Hap and I, and I'll show you all the towns. America is full of beautiful towns and fine, upstanding people. And they know me, boys, they know me up and down New England. The finest people. And when I bring you fellas up, there'll be open sesame for all of us, 'cause one thing, boys: I have friends. I can park my car in any street in New England, and the cops protect it like their own. This summer, heh? (Act. 1, p. 19)

Willy: ..... I always felt that of a man was impressive, and well-liked, that nothing- (Act. 2, p. 72)

Willy: ...... Ben, that funeral will be massive! They'll come from Maine Massachusetts, Vermont, New Hampshire! ....... Ben, because I never realized-I am known! Rhode Island, New York, New Jersey-I am known, Ben, and he'll see it with his eyes once and for all. He'll see what I am, Ben! (Act. 2, p. 100)

Willy's perception of being 'well-known' and 'wellliked' as the key to success that he believes will help him to attain his dream is his achievement in the American Dream. He wishes to be a wealthy salesman because he believes once he becomes rich he will change the social status. This can be a strong influence of capitalism that embodied in American's life. As we know, the major characteristic of capitalism is the separation between owners of the means of production (capitalist or bourgeoisie) and non - owners of the means of production (workers, laborers or proletariat) (Illegbinosa, 2012). In this drama, Willy is a middle class person (workers/proletariat). He believes by changing his social status to be a rich salesman (bourgeoisie) he can get a better life and be respected by other people. It is because in a capitalist society, workers are, in principle, underpaid; the value of labor expended in a day's work exceeds the wages paid for that work. It can be seen when Willy only working in commission and in his old age his bosses take his salary away.

Linda: A small man can be just as exhausted as a great man. He works for a company thirty-six years this March, opens up unheard-of territories to their trademark, and now in his old age they take his salary away

Biff: He's off salary. My God, working on commission! (Act. 1, p. 40)

Those are the facts that Willy faces hardship in life while he tries to achieve his dream and finally lead to downfall and tragedy. It indicates that the American Dreams are not easily reached by only being 'well known' and 'wellliked.' From Willy's tragedy, the researcher sees the misperception of the American Dream because some theories of American Dreams are not only mention about being 'well-known' and 'well-liked' to be successful. According to Datesman, Crandal, and Kearny (2014), one of the American values is material wealth and hard work. These values are very relevant with Willy's phenomena, he wants 
to be a rich salesman because he believes when he becomes a rich salesman he will find his happiness and prosperity. It seems that Willy has subordinated by capitalism since American seemed to be a land of abundance where millions might come to seek their fortune. However, the fortune cannot be achieved instantly, many people suffered terribly, but most of them eventually improved their former living standard. They have to do a hard work. Willy Lowman, looks like, missed this part because his life is full of desperate and less confident. Another value that has to be noticed carefully is competition. According to Perry (2000) Americans firmly believe that a highly competitive economy will make the best of its people and, eventually, that a culture that encourages competition will make the most significant change. In this play, the development of the notion of competition reveals the negative aspects within the Lowman family and eventually is the sole cause of Willy's downfall in life. This is evident through; Willy's desire for his sons to be more successful than Bernard. He says:

Willy: That's just what I mean, Bernard can get the best marks in school, y'understand, but when he gets out in the business world, y'understand, you are going to be five times ahead of him. That's why I thank Almighty God you're both built like Adonises. Because the man who makes an appearance in the business world, the man who creates personal interest, is the man who gets ahead. Be liked and you will never want. You take me, for instance. I never have to wait in line to see a buyer. "Willy Loman is here!" That's all they have to know, and I go right through. (Act.1, p. 20)

Willy sees that Bernard has a better academic record than Biff and Happy, but he believes that his sons will be more successful in the future because Bernard is not wellliked. The second is Willy's ambition to be more successful man than Charley. Next is his dream to be the most admired salesman, well-liked and loved. From Willy's competitive soul, however, he is not truly developing himself and raising his sons to be successful in life. Otherwise, he has a wrong mindset that popularity overcomes hard work and determination. He wants to have a success but he does not want to work hard. These phenomena prove that not all American Dreams are attainable to all people and this is the dysfunctional of American Dreams.

\section{The Failure of Willy Lowman}

Willy Lowman, in his sixty-three-year-old, has been passing many obstacles. His whole life is a succession of missed opportunities, and he considers himself a failure because of it. Willy has failed to drive to his business appointment, and he is going to miss out on making a sale because of it. The Lowman family's failure to reach their extraordinary dreams is sole because he believes that the key to success is popularity. As a matter of facts, Willy wants to be a wealthy salesman. Unfortunately, in his business today, he has lost his reputation and unable to make any money. Here, if a man's role is to earn money for his family, then Willy is a total failure. This is because the key to success is not only being popular but there are many aspects that have to be considered.

The same case happens when Willy considers Biff's life a failure because he is not making enough money or working in the business world. Willy thinks that Biff is slacking of working as a farmhand, "How can he find himself on a farm? Is that life? a farmhand; Willy has high expectations for Biff, “...In the beginning, when he was young, I thought, well, a young man, it's good for him to tramp around, take a lot of different jobs"(Act. 1, p. 5); Willy expects that Biff will make it big in business based on Biff's popularity in high school and Willy sees different reality. $\mathrm{He}$ is so dissatisfied with everything Biff does, “...But it's more than ten years now, and he has yet to make thirty-five dollars a week!'(Act. 1, p. 5). It looks like Biff cannot find a job that suits him, and although he has a useful life in Texas with his farmhand job, he gets panic because it is not the kind of job Willy expected him to have.

Willy truly bemoans the missed opportunity of going to Alaska with his brother, Ben, "Sure, sure! If I'd gone with him to Alaska that time, everything would've been totally different."(Act. 1, p. 31) It is because he cannot even drive himself to the sales appointments, and he cannot do his job as a salesman. Willy also is a failure when compared to his father. Ben asserts that he could sell more in a week than Willy could in a lifetime, “... Great inventor, father. With one gadget he made more in a wen than a man like you could make in a lifetime."(Act. 1, p. 34) Willy, when measured against Ben, does not fare much better, because Ben was rich by the time he was twenty-one, "... and when I was twenty-one I walked out. [He laughs.] And by God I was rich."(Act. 1, p. 33) Nevertheless, Willy sees this story differently. Ben stumbled across his wealth, but Willy believes that Ben worked hard for it and Willy wants his sons to do the same; work hard and be like Uncle Ben. However, Willy may forget that he is not implanting this value (hard work) to his sons. He only believes that they can be successful through their popularity.

Last but not least, Willy expected the funeral would be massive because he was so well known and well-liked. His funeral will prove to Biff that his father's life is worth something, but it does not turn out this way. The only people at Willy's funeral are his family, Charley, and Bernard. Willy Lowman died a failure by his standards. Biff considers Willy's life to be a failure because he had the wrong dreams. He could have been a successful salesman when he was qualified to work with his hands. If he had followed the right 
dreams and confronted his abilities realistically and honestly, he might not fail, and his life may not end that way.

The discussion above is in contrast with two American Values such as material wealth/materialism and popularity. According to Perry (2000), American dream concept itself which refers to the American values and beliefs such as materialism and popularity is the ideals that may not simply define the truth of American lives. For instance, all Americans might have the same opportunity to success but it is not always implemented ideally. Those who born into rich family will have more chances than those who born into poor family. It indicates that everyone who lives in America and believes in American dream has a possibility of undergoing the failure of his/her life. Moreover, Willy's failures demonstrate that not all the American dreams are attainable. Willy also indirectly depicted how capitalism system is. He is stuck in his capitalism mindset where American life also obviously implements the capitalist system.

In fact, this play expresses the family's struggle to make mortgage payments, a long-time employee laid off without warning, and ill and aging parent afraid of becoming a financial burden to his grown children. The story obviously exposes social structure between the bourgeoisie and the proletariat. Ilegbinosa (2012); Tamuno (1999); and Harvey (1999) state that the major characteristic of capitalism is the separation between capitalist or bourgeoisie and workers, laborers or proletariat. These two classes are in direct competition with one another. Therefore, Castle (2018) assumes that in capitalist society, both different classes can be distinguished by their material wealth. Money in the form of capital is always subject to fluctuations of the market, boom periods and crises which cause the value of money to rise or fall depending on whether or not capital is in high demand. In line with Castle, Ilegbinosa (2012) depicts that the capitalists place a higher value on the monetary value of man rather than the unique characteristics of each person. So, those who are strong will be the winner, and those who are weak will be the looser.

\section{The Causes of Willy Lowman's Dysfunctional American Dream}

\section{Willy Lowman's Reconstruction of Past Realities}

The problem emerges because Willy reacts to the characters in the present while simultaneously reacts to different characters in the past. Regarding to phases of time, Willy's behavior changed, such as sensitive mood, contradictory, obsessive, and ambitious. This can be inferred from the scene when Willy's thought is always clouded by a series of lucid memories wherein he remembers the past. Willy Lowman has different realities. There is a Willy Lowman, an exhausted man, financially burdened, and disorganized in his sixty-three-year-old, and there is also more passionate young Willy in some fifteen years ago, who appears in flashback in the play. That is the way Willy always daydreams about a happier moment when his sons loved him and he was successful in his business. Historically, according to Lethbridge and Jamila (2004) the play was written in 1949 after the Second World War (1939) and American Great Depression (1929 - 1939). These two tragic events are assumed more or less influenced the play where the economic condition of that time was very worse, but shortly after, Americans tried hard to better the economy through hard work, optimism, and fair competition.

This is one of the dysfunctional of American Dream in future orientation value. According to Perry (2000), most Americans believe that the future will bring improvement to their lives if they committed themselves to make progress in society through change. However, Willy only prides about his past but he cannot prove anything in the present. He thinks about the future and has many big dreams without considering anything from many aspects. In this case, it shows in every dialogue when Willy talks to the other characters in the present and he simultaneously reacts to the character in the past.

\section{The Desperation of Willy Lowman}

Willy is obsessed with the American Dream of fame, fortune, happiness, and prosperity. He shows the equation of the pursuit of money with the pursuit of happiness. Hence, that is why most of his dreams always concerning with money, business matter, and popularity. Everything in his life is always connected with money, "... You'll retire me for life on seventy goddam dollars a week?..." (Act. 1, p. 28); "Well, I-I did-about a hundred and eighty gross in Providence. Well, no-it came to-roughly two hundred gross on the whole trip." (Act. 1, p. ); "...You are not applying for a boy's job. Money is to pass..." (Act. 1, p. 47) Willy always shifts his head to find the way to get his business world, "A hundred and twenty dollars! My God, if business don't pick up I don't know what I'm gonna do." (Act. 1, p. ); "A business suit, and talk as little as possible, and don't crack any jokes." (Act. 1, p. 47)

Theoretically speaking, those are the examples of materialism mindset that embodied in American's mind. However, a lot of people have a misunderstanding about this, also Willy. According to Perry (2000), materialism is one of the American values that they can enjoy their prosperity and become more materialistic by measuring their success by the number of things they bought and owned. Kohls (1984), however, emphasizes that materialism is a material that is seen by hard work and serious intent as a natural benefit. Thus, Willy definitely can achieve his dreams by working hard and changing his mindset about being successful, not only seen from how much money he 
has and how popular he is. Another point of view, from a capitalist theoretical perspective, Castle (2018) mentions that money functions in the capitalist system of values as another form of value, one that is determined within the economic system in which it is used as an equivalent value for a specific commodity. Money in the form of capital is always subject to fluctuations of the market, boom periods, and crises, which cause the amount of money to rise or fall depending on whether or not capital is in high demand. The commodity form is essential to understanding capitalism of the social totality. This theory is related to Willy's life when his life is money-oriented to get his success. He lives in a society where the American Dream dominates people's minds, and his purpose in life is to make it happen, to have a better life, and to treat his family in the right way.

Notwithstanding, he has big dreams in his life with his conviction about the keys to success, it soon brings him to the abyss of failure and desperation. Willy's big ideas, unfortunately, bring him up to the life that full of fantasy, and because of his inability to fill his dreams up, he has deep desperation in his life. Miller expresses the Willy's desperation almost in every Willy's scene in this play, "They don't need me in New York. I'm the New England man. I'm vital in New England." (Act.1, p. 4) This dialogue shows when Willy Lowman is responding to his wife's suggestion that he should try a job at his New York office.

Willy's response shows how completely he can identify with his career. Willy's position in New England is inflated to cover up the reality that the New York office does not need it. Willy's self-importance barely conceals his fear that he would not be required in New England either. Willy's mental survival depends on his belief that he is essential, which is why he often deceives himself throughout the play. Willy's mind filled by a lot of regrets that bring him into never ending desperation. Miller also wrote, "I'll have to send a wire to Portland. I'm supposed to see Brown and Morrison tomorrow morning at ten o'clock to show the line. Goddammit, I could sell them! [He starts putting on his jacket.]"(Act.1, p.4) This passage is relevant because it defines Willy and shows us just how much he does not understand himself. Because Linda tells Willy that he is sixty-three-year-old and too old to keep working, the audience would expect Willy to heed the advice and cut back on how much he's doing.

However, Willy, who is, does precisely the opposite, believing that he is still the best salesman in the world. The audience knows that he's not nearly as glorious as a salesman as he's showing himself that Willy is very selfdelusive. The author says it is through Willy's point of view to make it clear to the audience that Willy is frantic about his abilities. This is because of Willy's fear for not being successful in life if he cannot plunge himself into a business world, "A hundred and twenty dollars! My God, if business don't pick up I don't know what I'm gonna do." (Act. 1, p. ); and he finally realizes that his big ambitious is imbalance with his ability and bring him into deep desperation, "Well, I figure, what the hell, life is short, a couple of jokes.

[To himself] I joke too much! [The smile goes.](Act. 1, p. 24); "I got an awful scare.... Why didn't I go to Alaska with my brother Ben that time! ... What a mistake! ... ." (Act. 1, p. 27); “... I get the feeling that I'll never sell anything again, ...'(Act. 1, p. 25); "Ben, nothing's working out. I don't know what to do."(Act. 2, p. 64); “Charley, I'm strapped, I'm strapped. I don't know what to do. I was just fired.”(Act. 2, p. 75); “... There's a big blaze going on all around, I was fired today."(Act. 2, p. 83); "Why? Does it take more guts to stand here the rest of my life ringing up a zero?"(Act. 1, p. 100); “Oh, Ben, how do we get back to all the great times?..."(Act. 2, p. 101). Those tones sound very pessimistic and unhopeful.

Additionally, Willy always repeats his loneliness, fatigue and optimism in life, "I'm tired to the death. [The flute has faded away. He sits on the bed beside her, a little numb.] I couldn't make it. I just couldn't make it, Linda."(Act.1, p. 2); “I'm so tired. Don't talk anymore."(Act. 1, p. 51); "I'm getting awfully tired, Ben.'(Act.1, p. 30); “...I couldn't get past Yonkers today! Where are you guys, where are you? The woods are burning! I can't drive a car."(Act. 1, p. 28) and it is not only from Willy side talking about his fatigue and desperation but also some characters evaluate him as a hopeless-man, "... The man is exhausted."

(Linda, Act. 1, p. 40); "A small man can be just as exhausted as a great man..." (Linda, Act. 1, p. 40); "He's dying, Biff." (Linda, Act. 1, p. 42); "He's been trying to kill himself."(Linda, Act. 1, p. 42); “There's one or two other things depressing him, Happy" (Biff, Act. 1, p. 10); "This is no time for false pride, Willy. You go to your sons and you tell them that you're tired..."(Howard, Act. 2, p. 63) Those dialogues are the symbolic expression, by which Willy means that his life is being destroyed by the situation. He is financially hard-up, he is on the verge of losing his job as a salesman, he is so lonely and exhausted. Something that hurts him even more is he not only feels himself a failure but also his sons.

His only refuge is by thinking back to the past when he is loved by his sons and the future seemed more promising. One of the interesting remarks is when Willy says the woods are burning to Happy, his younger son, who was trying to cheer him up by promising him that, "I'm gonna retire you for life"(Act. 1, p. 28) Willy is contemptuous of this because Happy does not make a lot of money, and what he does is pay rent on his apartment and women. His other son, Biff, does not have a regular job. The lack of success of his sons 
makes Willy feel worse. Willy thinks that his life has turned out to be wrong and that it's all going to end in disaster-as it does when he ends up committing suicide.

Accordingly, regarding to Willy's long and deep desperation, the researcher firmly believe that this is one of the strong reasons of Willy's dysfunctional of American Dreams. However, according to Fiedler (2000), one of American beliefs is that ignoring the social status, one can achieve a better life through hard work, sacrifice, and strong will. This notion refers to equality that all people have the same opportunities to have a better life through hard work, sacrifice, and strong will. Nonetheless, by seeing Willy's desperation phenomena, it indicates that Willy has lack of hard work and strong will. He should not get the desperation if he has a strong will and do a hard work. Willy might has done educate their family to think the future and he believes that the future is good and obvious but he has not realized that he also has to elevate his optimism in life. As Perry (2000) mentions that the future will bring improvement to Americans if they commit themselves to make progress in society through change.

\section{The Effects of Dysfunctional American Dreams to Willy Lowman \\ Willy Lowman's Tragic Life}

Willy Lowman is a man with big goals in his life. He has a lot of potentials, but he also has a whopping case of selfdeception paired with misguided life goals. Miller emphasizes this condition near the end of the play through Biff's dialogue with Willy, "I'm not a leader of men, Willy, and neither are you. You were never anything but a hardworking drummer who landed in the ash can like all the rest of them! ..." (Act. 2, p. 105). This passage shows that Biff confronts Willy. Biff tries to express his own need to stop deceiving himself in his efforts to fulfill his father's dreams. Biff blows the whistle on Willy's constant rationalization of his lack of success. Biff's coming to terms with his selfdeception is the moment he finally finds himself, seeing himself as he is. His emotional outburst leads to Willy's recognition that his son loves him, implying that it is when self-deception comes to an end that genuine care is possible.

Willy also believes that his career as a well-liked salesman will bring him to be successful. However, after passing his life journey to preach his dreams, he gets a total disaster in it. Willy is an anxious man who tries to make himself seem reasonable by pretending that he is a successful man among the people around him. In his delusion world, Willy seems a successful man, very popular, and has a good life. He conceals his self-doubt and solicitudes by his audacity and inflexibility. Nevertheless, an act of pretending is painful and will not last long.

Willy periodically cannot maintain his image of strength; he gives up and starts to ask some guidance or supports from successful people around him, whether in the present or past time. In this situation, Willy faces two realities that make him more disorganized. The first effect of his failure is he gets an emotional instability and brings him into unhealed desperation. He has a short-temper when interacting with other even with his wife. It occurs when Willy has a discussion with his family and he yells at his wife.

Willy repeatedly says "stop interrupting" (Act. 1, p. ) in a high tone and it makes Biff furiously says, "Stop yelling at her!" (Act. 1, p. 48). It also happens when Willy easily feels insulted by others. He, once, has a conversation with Charley and always repeats the word don't insult me" (Act. 1, p. 29, 30; Act. 2, p. 74). The fact is Charley does not insult Willy, it is the only way Charley utters the truth to help Willy's reality of life. This is also an implementation one of the American values, Directness. Kohls (1984) states that directness is one can only trust people who "look you in the eye" and "tell it like it is" and truth is a function of reality not of circumstance. Thus, the researcher firmly believes that Willy is not ready to face the reality and hardly accept any advices from others. Whereas, Perry (2000) believes that communication in America is direct, open, and blunt.

The second effect of his failure is he experiences a death of hope. He becomes a hopeless and pessimist man. This apparently is shown by Miller in some Willy's dialogues which demonstrate his hopelessness. After all the highways, the trains, the appointments and the years, you end up worth more dead than alive" (Act. 2, p. 76). It indicates that Willy is lamenting the worthlessness of all his years of work. He realizes that he never earns enough money, and even though his American dreams say "... I'd like build a little guest house ..." (Act. 2, p. 53); "I could build two guest houses ..." (Act. 2, p. 53). The fact is he does not build anything, and his job has nothing left. He is a livelihood worker and he realizes that he has a high dependent of life insurance policy that drives him into suicide. Another dialogue demonstrates, "I've got to get some seeds. I've got to get some seeds, right away. Nothing's planted. I don't have a thing in the ground" It is an analogy when Willy realizes that his entire career has built up to nothing.

All Willy's desperation and hopelessness utterances show that the American dream is unattainable. None of the Lowman family does achieve his or her goal. Ironically, Willy's failure drives him to end his life by committing suicide. In the last scene of this play, Willy comes back into the past memories and talk to Ben. Unfortunately, this conversation provokes Willy's desire to commit suicide because Ben reminds Willy of the twenty thousand dollars insurance policy, "It's dark there, but full of diamonds" (Ben, Act. 2, p. 108); "Can you imagine that magnificence with twenty thousand dollars in his pocket?" (Willy, Act. 2, p. 109). 
The dialogues, additionally, the diamond refers to a tangible reminder of the material success that Willy's job cannot offer him and the missed opportunity of material success with Ben. It symbolizes that Ben convinces Willy to commit suicide because he transforms suicide into a brief opportunity that must be measured. Thus, Willy believes that Biff will respect him if he commits suicide in order to gain the policy. Willy, finally, drives away and runs into his death. According to Hayman (1970), Willy, therefore, refers to the character that we usually call as a tragic I-hero. Willy is a hero for his family. He is a responsible father that always looks for a better life and tries to treat his family in the right way. Unfortunately, because of his misconceptions of the American dreams and some other factors make his life ends tragically. The letter "I" refers to Willy's psychology that has not been stable and finally ruins his life, his family as well.

Tragically, however, in Willy's funeral, nobody comes, except the Lowman family, Bernard, and Charley. It indicates that Willy is not a popular and well-liked person. He contradicts his own intentions. Rather than illustrating the fact that he was "well-liked," his unimpressive funeral demonstrates his mediocrity. Even his son, Biff, still deems that Willy has a misguided goal, "He had the wrong dreams. All, all, wrong" (Requiem, p. 111); "He never knew who he was" (Requiem, p. 111). Nonetheless, Charley delivers his wise speech that nobody understands Willy's suicide, and it cannot be justified because it defies Willy's intentions. Willy believes that his suicide will resolve the disorder in his life by alleviating any pain Linda has caused, winning Biff's respect, and demonstrating his popularity as a salesman and an individual. In reality, he denies a debt-free husband to Linda, a reconciled father to Biff, and an improved role model to Happy. Thus, Willy is unprepared to face his reallife, and it makes a disorder in his family.

Last but not least, Happy firmly states that "Willy Lowman did not die in vain" (Requiem, p. 111), but Willy did die in vain, and no one can change the destiny. Throughout this analysis, Willy Lowman is a figure who vigorously ambitious in life. However, he completely fails to preach his American dreams because he walks through his life blindly. Arthur Miller's Death of a Salesman is a masterpiece that interprets unattainable American Dreams since it is known as an opportunity to get a better life and pursuit of Happiness. From this play, the researcher strongly believes that not all American values are suitable for the Americans, and it can be said as the dysfunctional American dream for Castle (2018) insists that the strong belief (ideology) on the capitalism system is a form of false consciousness. The influence of capitalism on Willy leads him to a very terrible failure that makes his dream unattainable or dysfunctional.

\section{CONCLUSION}

The researcher found that the writer of the play, Arthur Miller, uses Willy Lowman's personality to indicate the dysfunctional American Dream. Willy's journey to find the American Dream leads to his failure because, throughout his life, he chases the apparition of the American Dreams and not the actuality of them. He has an intense obsession with perfection. His success mindset has formed, such as having an excellent job with a high salary, having a great family, being well-liked, happy, and prosperous. Arthur Miller's Death of a Salesman described social situation of American Society indirectly. Furthermore, Arthur Miller wrote this drama after The Great Depression and it depicted how the American condition at that time. From mimetic approach perspective, Willy illustrated that most of Americans have different concept in understanding American Dream. Their life orientation led to materialism, liberty, and equality. This study obviously demonstrates that not all Americans or immigrants have the same perception of the American Dreams and not all of them can reach the Dreams. Sometimes, American Dream is a utopia since the dreamers could not measure their ability.

\section{ACKNOWLEDGEMENTS}

In arranging this journal, we would like to thank English Language Education Department, Faculty of Teacher Training and Education, University of Muhammadiyah Malang that has given opportunity to finish the research.

\section{REFERENCES}

Abrams, M. H. (1971). A glossary of literary terms. Holt, Rinehard and Winston, Inc.

Adam, J. T. (1959). The epic of America. Little Brown Press.

Can, S. (2019). Tragic death of a salesman: A hegelian perspective. International Journal of Humanities and Cultural Studies (IJHCS), 6(1), 36-44.

Castle, J. J. (2018). Electoral Choice and Religion: United States. In Oxford Research Encyclopedia of Politics.

Datesman, Crandal, and Kearny. (2014). American ways: An introduction to American culture. Pearson Education ESL.

Eagleton, T. (1991). Significance of theory. Wiley Black Well P.

Elhawa, H. A. (2018). Desire and American dream in the deat of a salesman. Angloamericanae Journal, 3(1). 18-28. http://aaj.ielas.org

Fiedler, Jansen, \& Norman-Risch. (2000). America in closeup. Pearson Education Limited.

Gailan, Mohammad. (2016). A marxist reading of Arthur Miller's death of a salesman. Akademin for Utbildning Och Ekonomi: Avdelningen for Humaniora.https://www.diva-

portal.org/smash/get/diva2:934498/FULLTEXT01.pdf 
Girling, J. (2002). Corruption, capitalism, and democracy. Routledge London \& New York.

Harvey, D. (1999). The limits to capital. Verso.

Hayman, R. W. (1970). Optimization of Vertical Alignment for Highways Through Mathematic. at Programming. Research Record, 1.

Hodgson, G. (2015). Conceptualizing capitalism. Chicago Press.

Ilegbinosa \& Anthony I. (2012). An analysis of Karl Max’s theory of value on the contemporary capitalist economy. Journal of Economics and Sustainable Development, 3. 1-6. https://iiste.org/Journals/index.php/JEDS/article/view $/ 1581$

Jefferson, T. (1776). The declaration of independence.

Kohls, L. Robert. (1978). Values American live by. Great Contemporary Issues.

https://www.fordham.edu/download/downloads/id/31 93/values_americans_live_by.pdf

Kumar, R. (2011). Research methodology: A step-by-step guide for beginners. SAGE Publications.

Lethbridge, S., \& Mildorf, J. (2004). Basics of English studies: An introductory course for students of literary studies in English. Tübingen: University of Tübingen.

Martin, A., \& Robert H. (1996). Modern novels: Introduction to modern English literature for students of English. Prentice Hall International.

Mgamis, M. S. (2017). Death of a salesman: Critique of the American dream. International Journal of Language and Literature June, 5. $69-71$.

Miller, A. (1994). Death of a salesman. Penguin Books.

Miller, A. (2015). The collected essays of Arthur Miller. 'Tragedy and the common man'. Bloomsbury Methuen Drama.

Nurgiyantoro, B. (2005). Tahapan perkembangan anak dan pemilihan bacaan sastra anak. Yogyakarta State University.

Nzisi, Perpetua M. (2017). Willy Lowman's perception of the American dream in Arthur Miller's play death of a salesman. International Journal of African and Asian Studies, 39. 85-91.

https://iiste.org/Journals/index.php/JAAS/article/dow nload/39184/40293.

Perry, B. (2000). A look inside America: Exploring America's cultural values and holidays. MultiLanguage Media, Inc.

Regan, P. (2012). Hans-Georg Gadamer's philosophical hermeneutics: Concepts of reading, understanding and interpretation. Meta: Research in hermeneutics, phenomenology, and practical philosophy, 4(2), 286303. https://core.ac.uk/download/pdf/26144385.pdf

Rose, P. I. (1997). They and we: Racial, ethnic, relations in the United States. The McGraw Hill Companies.

Selden, R., Peter W., \& Peter B. (1997). A reader's guide to contemporary literary theory. PrenticeHall.

Sugiyono. (2010). Metode penelitian kuantitatif kualitatif dan RnD. Alfabeta.
Tamuno, S. O. (1999). A synoptic view of economic theorists. African Heritage Publications.

Teeuw, A. (1984). Sastra dan ilmu sastra, pengantar teori sastra. Pustaka Jaya.

Tocqueville, A. D. (1945). Democracy in America. Vintage Books/Random House.

Warner, W. L., Meeker M., \& Eells K. (1949). Social class in America: A manual of procedure for the measurement of social status. Science Research Associates, Inc.

Weber, M. (1947). The theory of social and economic organization (T. Parsons, Trans.). Oxford University Press.

Wellek, R., \& Autin W. (1949). Theory of literature. Brace \& Company.

Wright, E. O. \& Shin K. Y. (1988). Temporality and class analysis: A comparative study of the effects of class trajectory and class structure on class consciousness in Sweden and the United States. Sociological theory, 6(1). 58-84.

Yin, R. K. (2011). Qualitative Research from Start to Finish. The Guilford Press.

Yuxian, Z. (2013). The embodiment of individualistic values in American nationality. Studies in Sociology of Science, 4(3). 36-42. http://www.cscanada.net/index.php/sss/article/view/j. sss.1923018420130403.2669

Conflict of Interest Statement: The authors declare that the research was conducted in the absence of any commercial or financial relationships that could be construed as a potential conflict of interest.

Copyright (C) 2021 Ivana Nabilah Qoriroh Mujahidah and Agista Nidya Wardani. This is an open-access article distributed under the terms of the Creative Commons Attribution License (CC BY). The use, distribution or reproduction in other forums is permitted, provided the original author(s) and the copyright owner(s) are credited and that the original publication in this journal is cited, in accordance with accepted academic prac- tice. No use, distribution or reproduction is permitted which does not comply with these terms. 